\title{
Article
}

\section{A Molecular Insight into the Synergistic Mechanism of Nigella sativa (Black Cumin) with $\beta$-Lactam Antibiotics against Clinical Isolates of Methicillin-Resistant Staphylococcus aureus}

\author{
Lorina I. Badger-Emeka ${ }^{1, *(D)}$, Promise Madu Emeka ${ }^{2}$ and Hairul Islam M. Ibrahim ${ }^{3}$ \\ 1 Department of Biomedical Sciences, Microbiology Division, College of Medicine, King Faisal University, \\ Hofuf 31982, Saudi Arabia \\ 2 Department of Pharmaceutical Science, College of Clinical Pharmacy, King Faisal University, \\ Hofuf 31982, Saudi Arabia; pemeka@kfu.edu.sa \\ 3 Department of Biological Sciences, College of Science, King Faisal University, Hofuf 31982, Saudi Arabia; \\ himo-hamed@kfu.edu.sa \\ * Correspondence: lbadgeremeka@kfu.edu.sa; Tel.: +966-(0)-536542793
}

\section{check for}

updates

Citation: Badger-Emeka, L.I.; Emeka, P.M.; Ibrahim, H.I.M. A Molecular Insight into the Synergistic Mechanism of Nigella sativa (Black Cumin) with $\beta$-Lactam Antibiotics against Clinical Isolates of Methicillin-Resistant Staphylococcus aureus. Appl. Sci. 2021, 11, 3206. https://doi.org/10.3390/app11073206

Academic Editor: Hari

Prasad Devkota

Received: 15 March 2021

Accepted: 31 March 2021

Published: 2 April 2021

Publisher's Note: MDPI stays neutral with regard to jurisdictional claims in published maps and institutional affiliations.

Copyright: (c) 2021 by the authors. Licensee MDPI, Basel, Switzerland. This article is an open access article distributed under the terms and conditions of the Creative Commons Attribution (CC BY) license (https:// creativecommons.org/licenses/by/ $4.0 /)$.

\begin{abstract}
Methicillin-resistant Staphylococcus aureus (MRSA) infection is detrimental to hospitalized patients. With diminishing choices of antibiotics and the worry about resistance to colistin in synergistic combined therapy, there are suggestions for the use of herbal derivatives. This investigation evaluated the synergistic effects of Nigella sativa (NS) in combination with beta-lactam ( $\beta$-lactam) antibiotics on extreme drug-resistant (XDR) MRSA isolates. NS concentrations of 10, 7.5, 5.0, 2.5, 1.0 , and $0.1 \mu \mathrm{g} / \mathrm{mL}$, alone and in combination with $\beta$-lactam antibiotics, were used to determine the antimicrobial susceptibility of MRSA isolates by the well diffusion method. Time-kill assays were performed using a spectrophotometer, with time-kill curves plotted and synergism ascertained by the fractional inhibitory concentration (FIC). Scanning and transmission electron microscopy were used to gain insight into the mechanism of action of treated groups. Isolates were inhibited by the NS concentrations, with differences in the zones of inhibition being statistically insignificant at $p<0.05$. There were statistically significant differences in the time-kill assay for the MRSA isolates. In addition, NS combined with augmentin showed better killing than oxacillin and cefuroxime. The mechanism of action shown by the SEM and TEM results revealed cell wall disruption, which probably created interference that led to bacterial lysis.
\end{abstract}

Keywords: Nigella sativa; methicillin-resistant; Staphylococcus aureus; synergism; beta-lactam; antibiotics

\section{Introduction}

The ongoing healthcare problems attributed to multidrug-resistant (MDR) bacterial infections that are difficult to treat continue to plague healthcare systems globally. Methicillinresistant Staphylococcus aureus (MRSA), one bacterium causing such an infection, remains a pathogen in various regions of the world [1]. Like all MDR bacterial infections, MRSAlinked infections can be associated with extended patient hospitalization, high morbidity, and mortality, especially in immunocompromised patients [1-3]. $\beta$-lactam antibiotics were the preferred drugs for the treatment of infections resulting from methicillin-resistant S. aureus. Vancomycin, a glycopeptide, still serves as the drug of choice in the treatment of MDR S. aureus infections. However, the bacterium has developed resistance to the $\beta$-lactams as well as vancomycin $[4,5]$. Thus, there is a decrease in the number of exogenous antibiotics for treating drug-resistant infections [3]. With a diminishing number of antimicrobials of choice, researchers have called for rationalization on the use of available antibiotics. This is intended to help reduce the rate at which MDR and pan-resistant bacterial superbugs are evolving to prevent the world from being taken back to the pre-antibiotic era $[6,7]$. Other suggestions are to look into alternatives to antimicrobial treatment due to 
bacterial resistance to systemic monotherapy that has overtaken the rate of production of new antibiotics [8]. One such alternative is the use of a combination of antibiotics [9]. It is postulated that such combined therapeutic measures could lead to successful management of patients with extreme drug-resistant (XDR) bacterial infections [10-12]. However, the double and triple combined antibiotic therapies suggested by the researchers were all colistin-based [13]. Presently, colistin is a last-line therapeutic option in the treatment of difficult bacterial infections. Besides the toxicity of the drug, there is a growing resistance to this last-line drug, as reported globally [14-17]. These reports necessitate the continued search for alternative antibiotic combinations that will exclude colistin in combined therapeutic measures [18]. There are also suggestions that such antibiotic synergistic combinations might not necessarily be the optimal options because it is thought that, as treatment progresses, there will be diminishing strength in antibiotic synergism [19]. However, as the problem of difficult-to-treat bacterial superbugs persists, the attention of researchers is currently focused on the use of herbal derivatives with antimicrobial properties, with suggestions that such plants could be synergistic enhancers [20,21]. It is thought that such combined therapy can help with expanding the spectrum of antibiotics as well as being less toxic while preventing the emergence of resistant bacteria strains [22].

Due to the expected significant advantages associated with phytotherapy, several researchers are now looking into the effectiveness of combinations of conventional antimicrobials and plant derivatives with antimicrobial properties [22-24]. This is expected to provide less toxic antimicrobial herbal alternatives that could be used as combined therapies in the treatment of XDR bacterial infections. One such plant reported by researchers in different regions of the world due to its impressive antimicrobial properties is Nigella sativa (NS), or black cumin [25-27]. In our previous study, we combined N. sativa with chloroquine in the treatment of malaria induced in mice with Plasmodium berghei [28]. The obtained results showed significant parasite clearance over a significant period, indicating that NS potentiated the effect of chloroquine when compared with chloroquine alone. Middle Eastern and Far Eastern countries have used Nigella sativa oil as a natural remedy or as a condiment/spice in food and food products from ancient times. As documented earlier, there is abundant evidence that Nigella sativa oil has been used in combination with synthetic medicines to treat various diseases due to its strong anti-inflammatory and antioxidant properties [28]. Studies have shown that Nigella sativa essential oil contains both volatile and nonvolatile bioactive compounds. It also contains alkaloids, saponins, and terpenoids, which are reported to possess antimicrobial activity [27]. Thymoquinone and thymol are the most reported active volatile constituents, possessing antitumor, antihistaminic, antidiabetic, antihypertensive, anti-inflammatory, and antimicrobial abilities. Numerous studies have reported the antimicrobial and antiparasitic activities [28].

The present work therefore looks at a possible synergistic effect of $N$. sativa with common antibiotics that show treatment failures with bacterial infections due to resistance to these drugs. The use of $N$. sativa with the aforementioned antibiotics could enhance their antimicrobial efficacy. This study aims at evaluating the synergistic effect of combining N. sativa with oxacillin (OXA), augmentin (AUG), and cefuroxime (CEF) on different XDR MRSA isolates, as well as looking into the possible mechanism of action of $N$. sativa on the isolates.

\section{Materials and Methods}

\subsection{Ethical Considerations}

Approval for the research was given by the Deanship of Scientific Research (approval number: 186388). MRSA clinical isolates were from routine hospital diagnoses for care of patients. They were from the microbial bank at the College of Medicine, Medical Microbiology division, of King Faisal University. 


\subsection{Bacterial Isolates and Antimicrobial Susceptibility Determination}

Six non-replicate clinical MRSA isolates from specimens of blood, sputum, pus, and wound swaps were used for the investigation. They had been stored in the Microbank of the Microbiology division of the College of Medicine, King Faisal University at a temperature of $-80^{\circ} \mathrm{C}$. They were cultured on blood agar and incubated aerobically at $37^{\circ} \mathrm{C}$ for $24 \mathrm{~h}$. Isolates were identified with a Vitek compact 2 automated system (BioMerieux, Marcy L'Etoile, France) using the Gram-positive ID cards according to the guidelines of the manufacturer. The antimicrobial susceptibility and minimum inhibitory concentrations were determined using the AST-GN cards of the Vitek 2 compact automated system (BioMerieux, Marcy L'Etoile, France). They were against the following antibiotics: augmentin (AUG), benzyl penicillin (BENZ), oxacillin (OXA), cefuroxime (CEF), cefuroxime/axetil (CEF/AXE), clindamycin (CLD), amikacin (AK), imipenem (IMP), ciprofloxacin (CIP), levofloxacin (LEVO), erythromycin (ERY), sulfamethoxazole/trimethoprim (SXT), tigecycline (TG), tetracycline (TET), rifampicin (RIF), and gentamicin (GEN). Confirmation of resistance against imipenem (IMP), tigecycline (TG), and amikacin was by disc diffusion method (Oxoid Ltd., Basingstoke UK). All of the MRSA isolates had been confirmed by the presence of the $m e c A$ gene.

\subsection{Nigella sativa and MRSA Susceptibility Test}

Nigella sativa (NS) black seed oil, a product of Al Hussan Food Products Factory, Riyadh was purchased from a local herbal medicine shop in Al-Ahsa, Saudi Arabia. According to the manufacturer, it is $100 \%$ pure organic cold pressed oil. Undiluted and diluted forms of the oil extract were used for the investigation. Oil extract was diluted in $0.2 \%$ dimethyl sulfoxide (DMSO) to obtain concentrations of $1000 \mu \mathrm{g} / \mathrm{mL}, 750 \mu \mathrm{g} / \mathrm{mL}$, $500 \mu \mathrm{g} / \mathrm{mL}, 250 \mu \mathrm{g} / \mathrm{mL}$, and $100 \mu \mathrm{g} / \mathrm{mL}$ dilutions, representing $100 \%, 75 \%, 50 \%, 25 \%$, and $10 \%$ concentrations. In these, $0.01 \mathrm{~mL}$ of each concentration was used to make the actual concentrations 10, 7.5, 5.0, 2.5, and $1.0 \mu \mathrm{g} / \mathrm{mL}$. The susceptibility of the isolates was tested against these dilutions of NS by the well diffusion method. Mueller-Hinton agar (MHA) was seeded with each bacterial isolate and spread out to cover the entire surface of the agar using sterile cotton swabs, moistened with the bacterial suspension [29,30]. Seven evenly distributed wells were punched into the MHA using a sterile cork borer of $6 \mathrm{~mm}$ diameter. The six NS dilutions were introduced into the wells aseptically, while the seventh well, serving as the control, was filled with an equal volume of $0.2 \%$ DMSO. All plates were allowed to diffuse under room temperature for $1 \mathrm{~h}$ according to the recommendations of the National Committee for Clinical Laboratory standards (NCCLS). All plates were incubated aerobically at $37^{\circ} \mathrm{C}$ for $24 \mathrm{~h}$ in an upright position. Experiments were carried out in three replicates with zones of inhibition measured in millimeters $(\mathrm{mm}) 24 \mathrm{~h}$ post-incubation, and the results are presented as means \pm standard deviation.

\subsection{Determination of Time-Kill Assay}

The CLSI guidelines were used for the determination of the time-kill assay using a nutrient broth (NB) [31]. MRSA bacteria strains 1, 4, and 5, which were randomly selected from six phenotypically different isolates, were inoculated into tubes containing NB to form a $5 \times 10^{5} \mathrm{CFU} / \mathrm{mL}$ bacteria suspension. They were each tested against combinations of NS, OXA, AUG, and CEF and for the time-kill assay. Tubes contained NB, a bacterial strain, and NS, while a second set had the bacterial strain, NB, NS, and one antibiotic. According to the McFarland standard, all bacterial suspensions were diluted to about $10^{6} \mathrm{CFU} / \mathrm{mL}$ and incubated aerobically at $37^{\circ} \mathrm{C}$ in an orbital shaker for $48 \mathrm{~h}$. At hours $0,1,3,6,24$, and $48,2 \mathrm{~mL}$ of each suspension were drawn out from each tube and inoculated into blood agar. The inoculum was spread out using sterile inoculating loops, with all plates incubated aerobically at $37^{\circ} \mathrm{C}$ for $24 \mathrm{~h}$. The viability of the MRSA isolates was evaluated by counting the bacterial colonies or noting the lack of microbial growth [3], while time-kill analysis curves were plotted with synergism, defined as described earlier [32,33]. 


\subsection{Antimicrobial Synergistic NS and $\beta$-Lactam Antibiotics Assay}

Bacterial strains were tested against the two concentrations of NS $(7.5 \mu \mathrm{g} / \mathrm{mL}$ and $5.0 \mu \mathrm{g} / \mathrm{mL}$ ) and each with the combination of the three $\beta$-lactam antibiotics to evaluate the synergistic activity with oxacillin (OXA), augmentin (AUG), and cefuroxime (CEF). The antimicrobial agents were used at their break points (OXA: $1 \mathrm{mg}$; AUG: 20/10 mg; CEF: $30 \mathrm{mg}$ ). Synergistic assay on MRSA strains 1, 4, and 5 was accessed using a spectrophotometer (BOECO, Hamburg Germany) with the additive/synergy effect calculated as earlier described $[32,34,35]$. Accordingly, the fractional inhibitory concentration (FIC) of each agent was calculated using the following formula:

$\mathrm{OD}_{600}$ of wells of agent in combination with the drug.

$\mathrm{OD}_{600}$ of wells of agent alone.

\subsection{Molecular Assay by SEM and TEM Microscopy}

SEM and TEM imaging were performed to evaluate the treatment effects on both the bacterial surface and within bacterial cells. The previously described method was used for the preparation of MRSA bacterial samples for scanning electron microscopy (SEM) [36]. Treated bacterial cultures as well as untreated samples that served as controls were incubated in a shaker incubator at $37^{\circ} \mathrm{C}$ for $24 \mathrm{~h}$. The resulting samples were centrifuged and prefixed in a $2.5 \%$ glutaraldehyde solution at $4{ }^{\circ} \mathrm{C}$ for $24 \mathrm{~h}$, after which they were rinsed in PBS and post-fixed with $100 \%$ acetone applied at the last stage. Gold sputtering was used to obtain a layer $20 \mathrm{~nm}$ thick. The images were obtained with SEM (JSM 6390 LA, JEOL, Tokyo, Japan) at a $15 \mathrm{KV}$ accelerating voltage.

Preparation and observation of TEM microscopy samples is as described previously, but with modifications $[37,38]$. Slices of selected MRSA bacterial samples were fixed by immersion in $2.5 \%$ glutaraldehyde (GA) in a $0.1 \mathrm{M}$ sodium cacodylate buffer with $\mathrm{pH} 7.4$ at a temperature of $4{ }^{\circ} \mathrm{C}$ for $1 \mathrm{~h}$, then washed in cacodylate buffer. All bacterial samples were double-fixed in $1 \%$ osmium tetroxide $(\mathrm{OsO} 4)$ in a cacodylate buffer at room temperature for $90 \mathrm{~min}$. They were then dehydrated in acetone and embedded in Epon-Araldite (502 kit, Pelco, CA, USA). Then, 500-1000 nm sections of bacteria samples were obtained in a Leica EM UC6 (Wetzlar, Germany), ultra-microtome mounted on glass slides, stained with 1\% toluidine blue stain. For light microscopy observations, bacterial samples were further dissected to 50-70 nm [37]. Staining of Epon-sectioned samples was carried out with the Leica automated EM stain ( $0.5 \%$ uranyl acetate and 3\% lead citrate). All samples' sections were scanned and examined using JEM 1011 (JEOL) electron microscope at $80 \mathrm{kv}$.

\subsection{Gas Chromatography/Mass Spectrometry (GC/MS) Analysis}

The extract of $100 \%$ pure organic cold pressed oil of Nigella sativa was analyzed by gas chromatography/mass spectrometry (GC/MS), and data were recorded on a GCMSQP2010 Plus (Shimadzu Corporation, Kyoto, Japan). The column used was a RTX-5MS ${ }^{\circledR}$ fused silica capillary $(30 \mathrm{~m} \times 0.25 \mathrm{~mm}$ i.d and $0.25 \mu \mathrm{m}$ film thickness); the oven temperature initially was held at $45^{\circ} \mathrm{C}$ for $2 \mathrm{~min}$ and then increased to $280^{\circ} \mathrm{C}$ at $4{ }^{\circ} \mathrm{C} / \mathrm{min}$. The carrier gas was helium with a flow rate of $2.0 \mathrm{~mL} / \mathrm{min}$; the temperature of the injector and detector were 250 and $300{ }^{\circ} \mathrm{C}$, respectively, the split ratio was 1:30, and the injection volume was $1 \mu \mathrm{L}$. The ionization energy for the mass spectrometer was $70 \mathrm{eV}$. Identification of components was confirmed from the mass spectra library.

\subsection{Statistical Analysis}

Data are presented as the mean $\pm \mathrm{SD}$ and the susceptibility analysis is presented in percentages. GraphPad Prism version 8.0 (San Diego, CA, USA) statistical software was used for statistical interpretation of the results. Two-way ANOVA, applying Tukey's multiple comparison test, was used to assess the statistical significance of zones of inhibition of various concentrations of NS on the different MRSA isolates. Additionally, one-way ANOVA, multiple comparison was used to compare the time-kill assay results and to 
determine the existence of any significant differences. Significance was taken to be $p<0.05$ and $p$-values were calculated between groups.

\section{Results}

\subsection{Antimicrobial Susceptibility of the MRSA Isolates}

The MRSA isolates in this investigation were highly resistant to other antibiotics, with the exception of tigecycline and gentamicin, with resistance of $17 \%$ and $33 \%$, respectively (Figure 1). The minimum inhibitory concentration (MIC) results are shown in Table 1. Differences in antimicrobial susceptibility and MIC values show that the isolates differ phenotypically. This difference is also seen in the antimicrobial susceptibility to the dilutions of NS, as shown in Figure 2 for all the MRSA isolates. All the isolates were inhibited by the various concentrations of NS, including the lowest concentration of $0.1 \mu \mathrm{g} / \mathrm{mL}$, as shown in Figure 2. The least effective of the NS concentrations against the MRSA isolates was $0.1 \mu \mathrm{g} / \mathrm{mL}$, which exhibited the lowest inhibitory effect among the isolates, with the exception of MRSA 2. Overall, there was no specific pattern in antimicrobial inhibition, as all the isolates responded differently to the NS dilutions. The mean zone of inhibition for MRSA 5 and 6 was more with the $10 \mu \mathrm{g} / \mathrm{mL}$ NS concentration, while MRSA 2 and 3 were inhibited more by the 7.5 and $5.0 \mu \mathrm{g} / \mathrm{mL}$ NS concentrations. For all the isolates, a comparison of differences in mean zones of inhibition between $10.0 \mu \mathrm{g} / \mathrm{mL}$ NS and 7.5, 5.0, and $2.5 \mu \mathrm{g} / \mathrm{mL}$ was not found to be statistically significant.

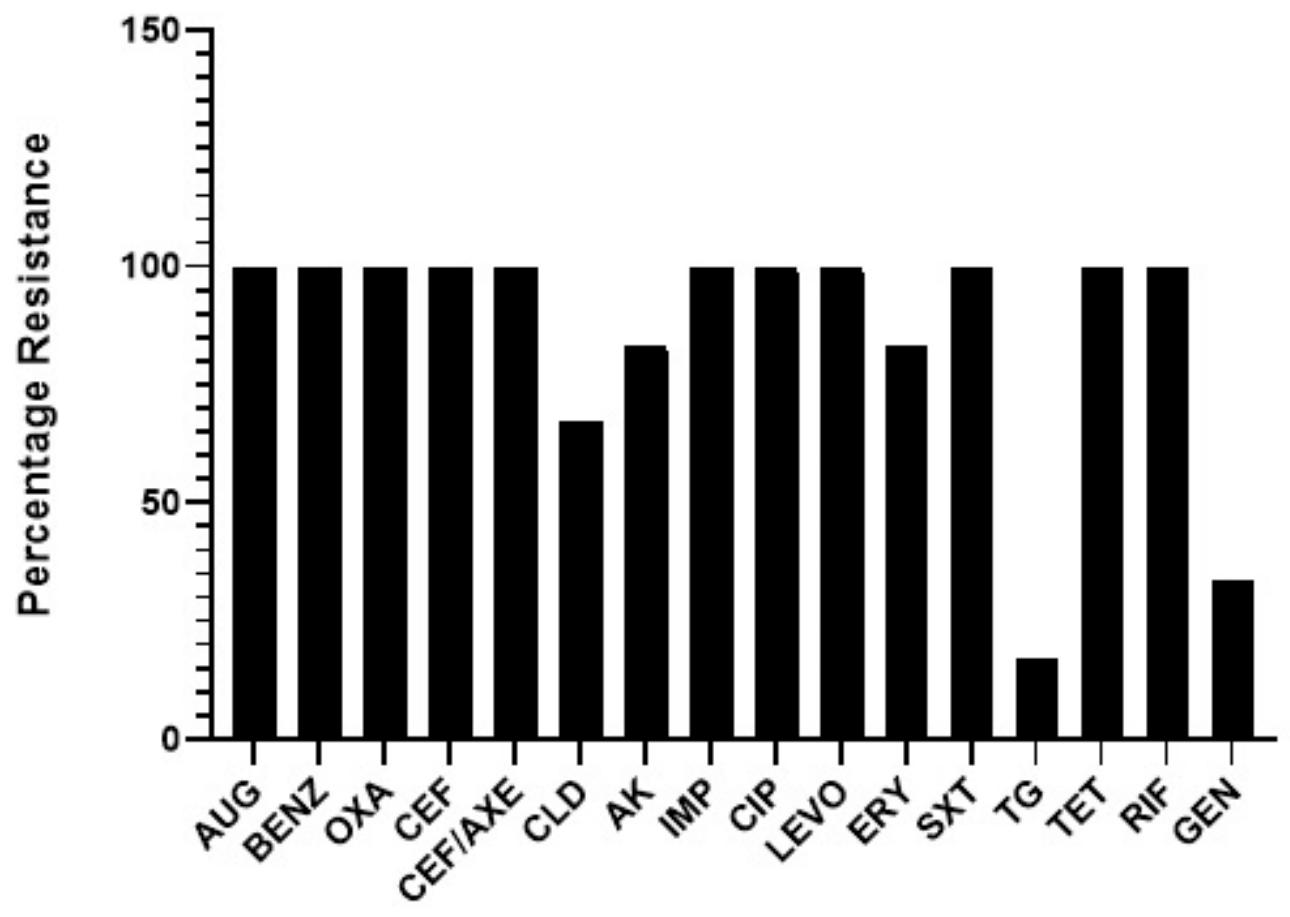

Antibiotics

Figure 1. Antimicrobial resistance of methicillin-resistant Staphylococcus aureus. Augmentin (AUG), benzyl penicillin (BENZ), oxacillin (OXA), cefuroxime (CEF), cefuroxime/axetil (CEF/AXE), clindamycin (CLD), amikacin (AK), imipenem (IMP), ciprofloxacin (CIP), levofloxacin (LEVO), erythromycin (ERY), sulfamethoxazole/trimethoprim (SXT), tigecycline (TG), tetracycline (TET), rifampicin (RIF), and gentamicin (GEN).

However, comparisons of the mean zones of inhibition for all the isolates with a $10 \mu \mathrm{g} / \mathrm{mL}$ NS concentration and with $1.0 \mu \mathrm{g} / \mathrm{mL}$ as well as $0.1 \mu \mathrm{g} / \mathrm{mL}$ showed statistically significant differences, with $p$-values of 0.034 and 0.0001 , respectively. Additionally, comparisons of the mean zones of inhibition resulting from $7.5 \mu \mathrm{g} / \mathrm{mL}$, when compared with those resulting from the lower NS concentrations, were statistically similar to those at 
$10.0 \mu \mathrm{g} / \mathrm{mL}$ NS. Differences in zones of inhibition between this $7.5 \mu \mathrm{g} / \mathrm{mL}$ NS concentration and the $1.0 \mu \mathrm{g} / \mathrm{mL}$ were significant ( $p$-value: 0.0012 ).

Table 1. Minimum inhibitory concentration of the MRSA isolates against tested antibiotics.

\begin{tabular}{|c|c|c|c|c|c|c|}
\hline Antibiotic & MRSA 1 & MRSA 2 & MRSA 3 & MRSA 4 & MRSA 5 & MRSA 6 \\
\hline Augmentin & $\leq 2$ & $\leq 2$ & $\leq 2$ & $\leq 2$ & $\leq 2$ & $\leq 2$ \\
\hline Benzyl penicillin & $\leq 0.25$ & $\leq 0.25$ & $\leq 0.25$ & $\leq 0.25$ & $\leq 0.25$ & $\leq 0.25$ \\
\hline Oxacillin & $\geq 4$ & $\geq 8$ & $\geq 8$ & $\geq 4$ & $\geq 8$ & $\geq 4$ \\
\hline Cefuroxime & $\leq 1$ & 8 & 2 & 8 & $\leq 1$ & $\leq 1$ \\
\hline Cefuroxime/Axetil & 8 & $\leq 1$ & $\geq 64$ & 8 & $\geq 64$ & 2 \\
\hline Clindamycin & $\leq 0.5$ & 2 & $\leq 0.5$ & $\geq 4$ & $\geq 4$ & $\geq 4$ \\
\hline Amikacin & $\geq 16$ & 8 & $\leq 4$ & $\geq 16$ & $\geq 16$ & $\geq 16$ \\
\hline Imipenem & $\leq 1$ & $\leq 1$ & $\leq 1$ & $\leq 1$ & $\leq 1$ & $\leq 1$ \\
\hline Ciprofloxacin & $\geq 8$ & $\geq 8$ & $\geq 8$ & $\geq 8$ & $\geq 8$ & $\geq 8$ \\
\hline Levofloxacin & $\geq 8$ & $\geq 8$ & 4 & $\geq 4$ & $\geq 8$ & $\geq 8$ \\
\hline Erythromycin & $\leq 0.25$ & $\geq 8$ & $\geq 8$ & $\geq 8$ & 1 & $\geq 8$ \\
\hline Sulfamethoxazole/trimethoprim & 8 & 16 & 16 & 8 & 16 & 16 \\
\hline Tigecycline & $\leq 0.12$ & $\leq 0.12$ & $\leq 0.12$ & $\leq 0.12$ & $\leq 0.12$ & 256 \\
\hline Tetracycline & $\geq 32$ & $\geq 32$ & $\geq 32$ & $\geq 32$ & $\geq 32$ & $\geq 320$ \\
\hline Rifampicin & $\leq 1$ & $\leq 0.5$ & $\geq 4$ & 2 & $\geq 4$ & $\geq 4$ \\
\hline Gentamicin & $\geq 16$ & $\leq 4$ & $\leq 4$ & $\leq 4$ & $\leq 4$ & 8 \\
\hline
\end{tabular}

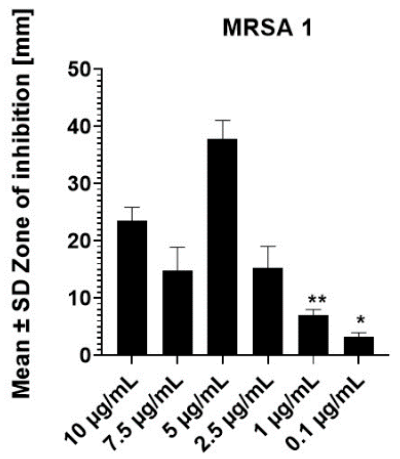

Final concentrations of Nigella sativa

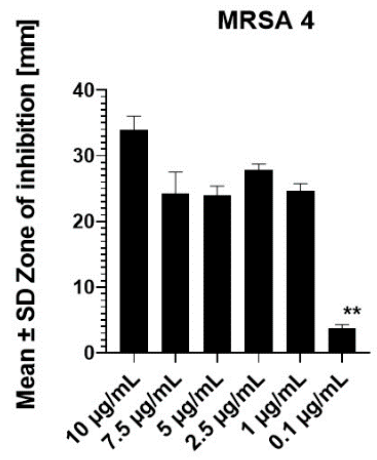

Final concentrations of Nigella sativa

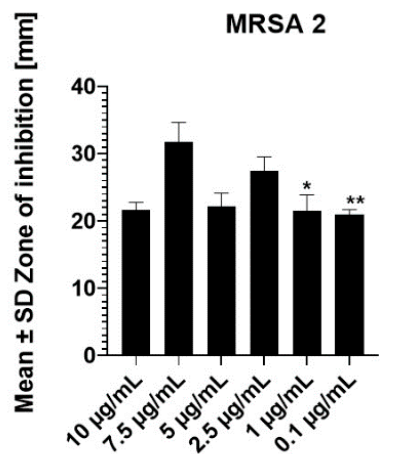

Final concentrations of Nigella sativa

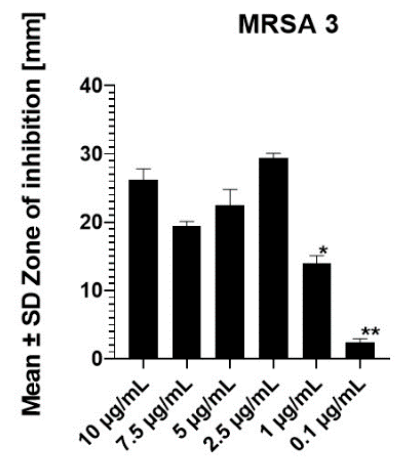

Final concentrations of Nigella sativa

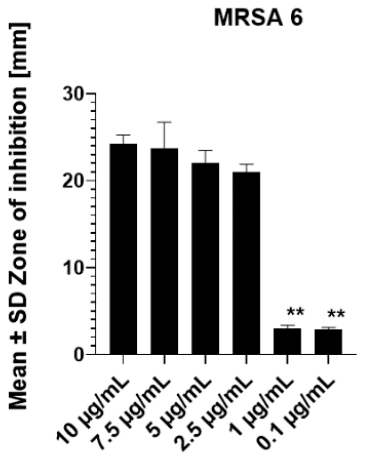

Final concentrations of Nigella sativa

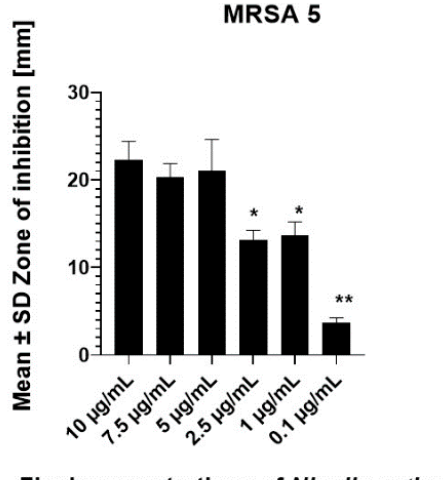

Final concentrations of Nigella sativa

Figure 2. Showing the zones of mean $\pm \mathrm{SD}$ inhibition of methicillin-resistant Staphylococcus aureus (MRSA), MRSA 1-6 bacterial isolates against Nigella sativa (NS) dilutions. Comparison of $10 \mu \mathrm{g} / \mathrm{mL}$ and other concentrations. ${ }^{*} p$-value: 0.034 ; ** $p$-value: 0.0001 . 
MRSA 1 was the isolate that was most inhibited by the $5.0 \mu \mathrm{g} / \mathrm{mL}$ NS dilution. As with the higher NS concentrations, differences in mean zones of inhibition were significant when compared with those of the 1.0 and $0.1 \mu \mathrm{g} / \mathrm{mL} \mathrm{NS}$, with $p$-values of 0.045 and 0.0002 , respectively. For the $2.5 \mu \mathrm{g} / \mathrm{mL}$ NS concentration, statistical differences in inhibition zones were significant when compared to the lower NS dilutions (Figure 2).

\subsection{Time-Kill Kinetics}

Results on the effect of NS alone, and NS in combination with oxacillin (OXA), augmentin (AUG), and/or cefuroxime (CEF) are shown in Figure 3A-F. There were variations in antimicrobial effects based on strains of MRSA, as well as the type of antibiotic tested. A rapid rate of killing was seen more often with combinations of NS and antibiotics than with NS alone.
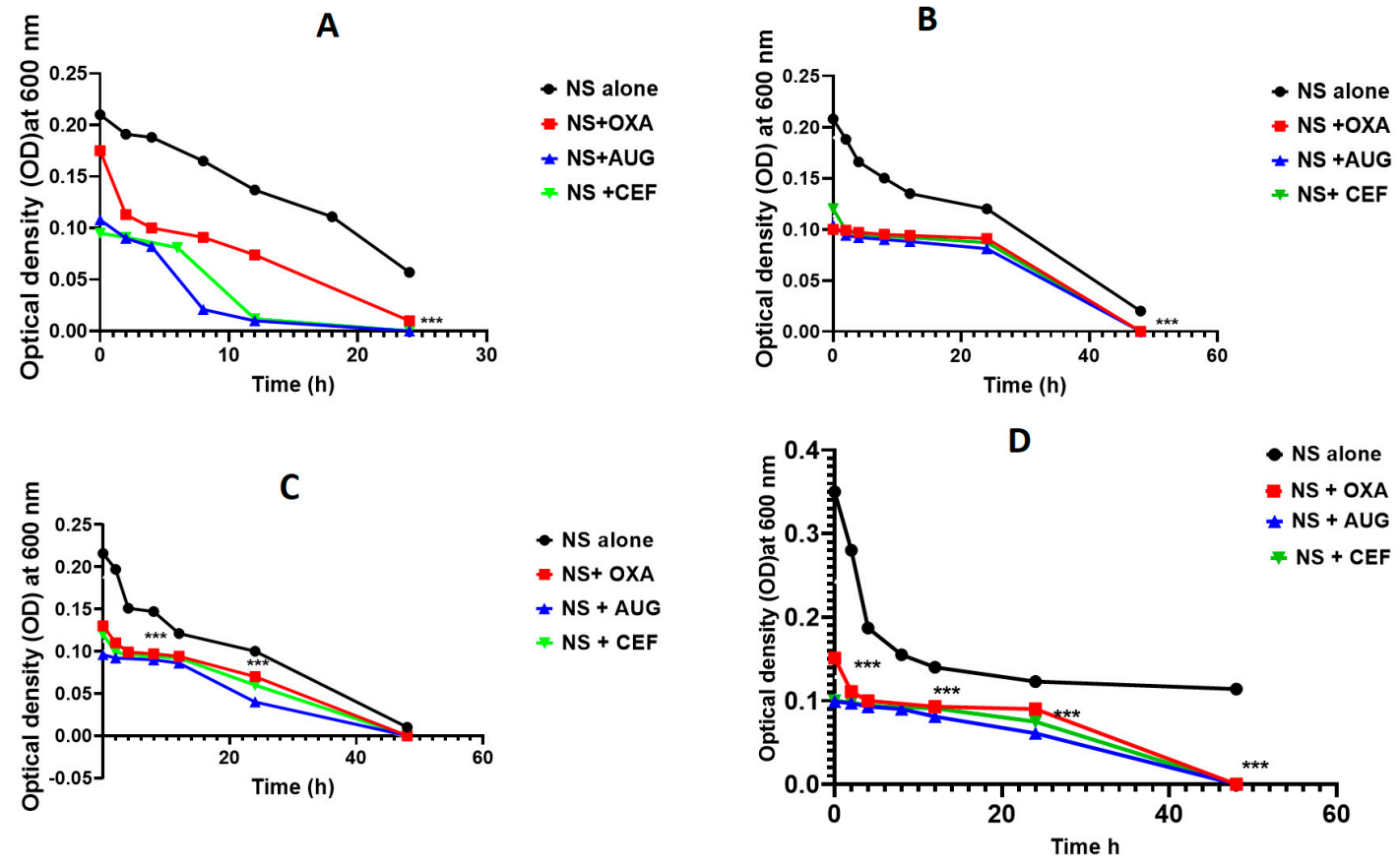

E
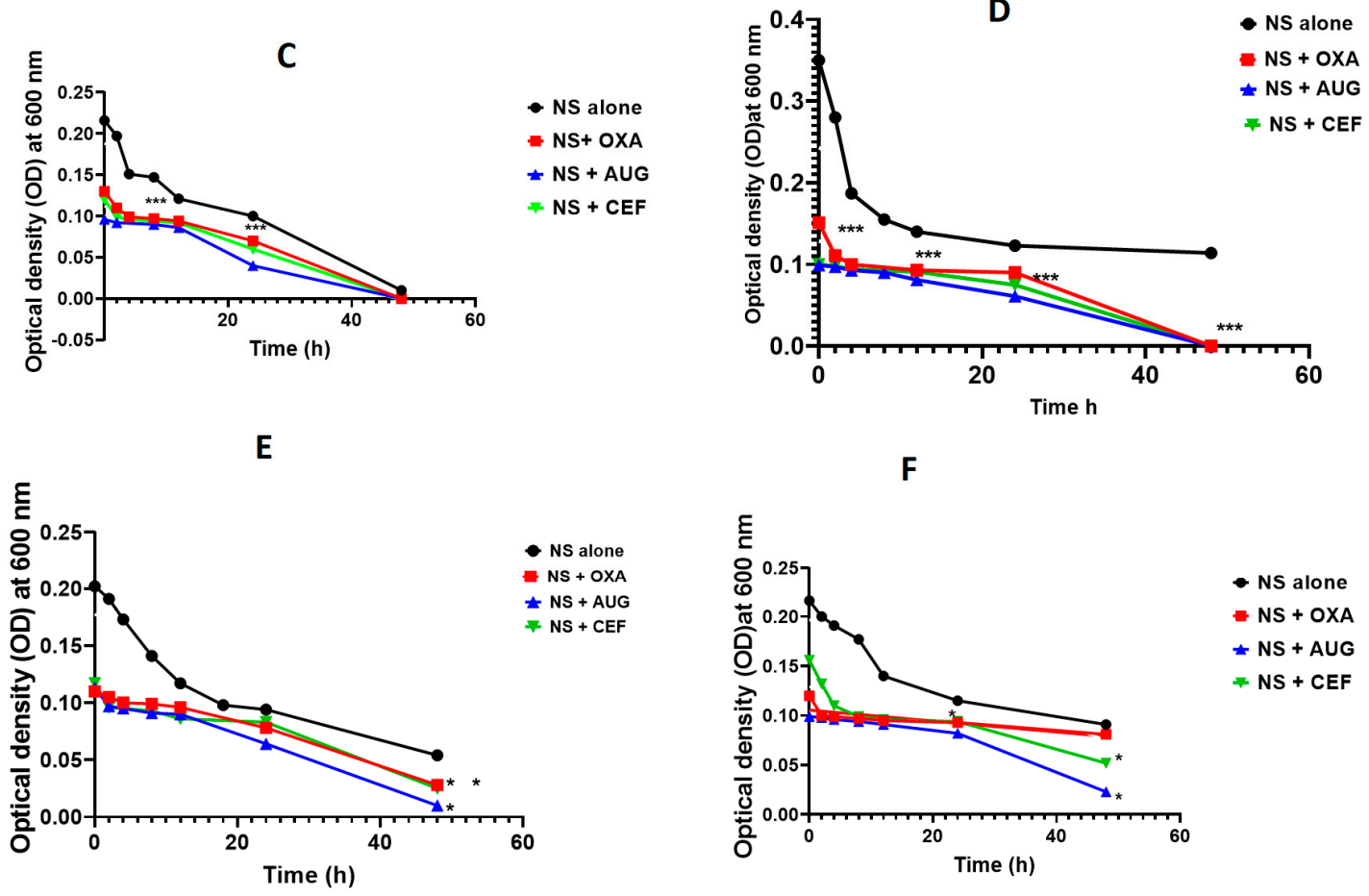

Figure 3. Time-kill assay curves of $7.5 \mu \mathrm{g} / \mathrm{mL}$ concentration of Nigella sativa (NS) alone and in combination with antibiotics against (A) MRSA 1, (B) MRSA 4, and (C) MRSA 5 bacterial isolates. (A) ${ }^{* * *}$ Represents significant values at $p<0.0039$ for NS + OXA, $p<0.0016$ for NS + AUG and $p<0.0142$ for NS + CEF; (B) ${ }^{* * *}$ Represents significant values at $p<0.0113$ for NS + OXA, $p<0.0061$ for NS + AUG and $p<0.0053$ for NS + CEF; (C) ${ }^{* * *}$ Represents significant values at $p<0.0179$ for NS + OXA, $p<0.0336$ for NS + AUG and $p<0.0180$ for NS + CEF. Time-kill assay curves of $5.0 \mu \mathrm{g} / \mathrm{mL}$ concentration of Nigella sativa (NS) alone and in combination with antibiotics against (D) MRSA 1, (E) MRSA 4, and (F) MRSA 5 bacteria isolates. (D) ${ }^{* * *}$ Represents significant values at $p<0.0408$ for NS + OXA, $p<0.0200$ for NS + AUG and $p<0.0494$ for NS + CEF; (b) * Represents significant values at $p<0.0331$ for NS + OXA, $p<0.0083$ for NS + AUG, and $p<0.0254$ for NS + CEF; $(\mathbf{F}) *$ Represents significant values at $p<0.0161$ for NS + OXA, $p<0.0019$ for NS + AUG and $p<0.0022$ for $\mathrm{NS}+\mathrm{CEF}$. 
In the combination of AUG with $7.5 \mu \mathrm{g} / \mathrm{mL}$ NS, the killing rate for MRSA 1 was more rapid than in combinations of NS with CEF and OXA in a time-dependent fashion, as shown in Figure 3A-C. Additionally, differences in these killing times were statistically significant when compared with the control ( $7.5 \mu \mathrm{g} / \mathrm{mL}$ NS alone). However, for the MRSA 1 time-kill kinetics, although antibiotic combinations with NS displayed a significantly difference in killing time, the time-kill kinetic curve between AUG and OXA did show a statistically significant difference, indicating that time-kill with AUG was more rapid. The results of the MRSA 5 time-kill assay showed significant differences between the NS and antibiotic combinations and NS alone. The killing times for $0-24 \mathrm{~h}$ were markedly different from those for $48 \mathrm{~h}$. Additionally, AUG displayed more rapid killing with respect to CEF and OXA. For this group of $7.5 \mu \mathrm{g} / \mathrm{mL}$ NS with antibiotic combination total killing was seen within $24 \mathrm{~h}$ for MRSA 1 and $48 \mathrm{~h}$ for MRSA 4 and 5 (Figure 3A-C).

The time-kill assay of the $5 \mu \mathrm{g} / \mathrm{mL}$ NS and antibiotic combination is shown in Figure 3D-F for the MRSA isolates 1, 4, and 5. The results showed complete killing for MRSA 1 at $48 \mathrm{~h}$ with combinations as compared with the effect of NS alone. The killing was rapid and statistically significant, with AUG showing a more rapid effect as compared to the control. In MRSA 4, the killing was not total but again AUG displayed rapid killing kinetics with CEF, with OXA showing similar rates of killing (Figure 3E). Additionally, for MRSA 5, there was no total killing after $48 \mathrm{~h}$. However, AUG displayed more rapid killing compared to CEF and OXA. In addition, the antibiotic combinations' time-kill kinetics were statistically significant compared to NS alone.

\subsection{Synergistic Effect of NS and $\beta$-Lactams with FIC Index Analysis}

The results presented in Table 2 are those of the FIC index interpretation that defines the time-kill assay synergistically for antibiotics and NS combinations. Combinations of $5.0 \mu \mathrm{g} / \mathrm{mL}$ NS with antibiotics on MRSA 1 displayed synergism. The best effect was with AUG, while the worst was with OXA. Synergism was observed within $4 \mathrm{~h}$ on isolates that exhibited extensive resistance to antibiotics. In MRSA 4, a similar pattern was observed, except that synergistic effects were seen for AUG and CEF within $4 \mathrm{~h}$, while with OXA, an additive effect was mostly displayed. For MRSA 5, the combination of NS with CEF had an additive effect compared with AUG and OXA, which displayed synergism within $8 \mathrm{~h}$. Overall, the study with $5 \mu \mathrm{g} / \mathrm{mL}$ combinations clearly indicates a synergistic effect.

Table 2. Fractional inhibitory concentration index synergy interpretation of different MRSA isolates measured at time intervals for combinations of $5.0 \mu \mathrm{g} / \mathrm{mL} \mathrm{N}$. sativa and antibiotics.

\begin{tabular}{|c|c|c|c|c|c|c|}
\hline \multirow{3}{*}{$\begin{array}{c}\text { Bacterial } \\
\text { Isolate/MRSA Type }\end{array}$} & \multirow{3}{*}{ Antibiotic Combination } & \multicolumn{4}{|c|}{ Fractional Inhibitory Concentration Index } & \multirow{3}{*}{ Outcome } \\
\hline & & \multicolumn{4}{|c|}{ Time (h) } & \\
\hline & & 2 & 4 & 8 & 12 & \\
\hline \multirow[t]{3}{*}{ MRSA 1} & NS + OXA & 0.4 & 0.5 & 0.7 & 0.7 & Synergism/Additive Effect \\
\hline & $\mathrm{NS}+\mathrm{AUG}$ & 0.3 & 0.5 & 0.6 & 0.5 & Synergism/Additive Effect \\
\hline & $\mathrm{NS}+\mathrm{CEF}$ & 0.4 & 0.5 & 0.7 & 0.6 & Synergism/Additive Effect \\
\hline \multicolumn{7}{|l|}{ MRSA 4} \\
\hline & $\mathrm{NS}+\mathrm{OXA}$ & 0.5 & 0.6 & 0.7 & 0.8 & Synergism/Additive Effect \\
\hline & $\mathrm{NS}+\mathrm{AUG}$ & 0.5 & 0.5 & 0.6 & 0.8 & Synergism/Additive Effect \\
\hline & $\mathrm{NS}+\mathrm{CEF}$ & 0.5 & 0.5 & 0.7 & 0.7 & Synergism/Additive Effect \\
\hline \multicolumn{7}{|l|}{ MRSA 5} \\
\hline & $\mathrm{NS}+\mathrm{OXA}$ & 0.5 & 0.5 & 0.5 & 0.8 & Synergism/Additive Effect \\
\hline & $\mathrm{NS}+\mathrm{AUG}$ & 0.5 & 0.5 & 0.5 & 0.7 & Synergism/Additive Effect \\
\hline & $\mathrm{NS}+\mathrm{CEF}$ & 0.7 & 0.6 & 0.6 & 0.7 & Additive Effect \\
\hline
\end{tabular}

NS = Nigella sativa, $\mathrm{OXA}=$ oxacillin; $\mathrm{AUG}=$ augmentin; $\mathrm{CEF}=$ cefuroxime. The interaction was defined as synergistic if the FIC index was less than or equal to 0.5 , additive if the FIC index was greater than 0.5 and less than or equal to 1.0, indifferent if the FIC index was greater than 1.0 and less than or equal to 2.0, and antagonistic if the FIC index was greater than 2.0. 
The synergistic time-kill assay, as interpreted with the FIC index for a $7.5 \mu \mathrm{g} / \mathrm{mL}$ NS combination with antibiotics, is shown in Table 2. The combination of OXA, AUG, and CEF antibiotics all displayed synergism, with AUG and CEF exhibiting the best synergism up to $12 \mathrm{~h}$. The pattern of synergistic effect on MRSA 4 was different, however. AUG had the best effect, but only for $4 \mathrm{~h}$, which was then followed by additive effects. In MRSA 5 , NS OXA combinations only produced additive effects. However, synergism was only observed for $2 \mathrm{~h}$, as indicated in Table 2 for AUG and CEF combination. The overall FIC index ranged from 0.05 to 0.7 , indicating synergism and additive effects.

\subsection{SEM and TEM Assay on Effect of Combined NS, Antibiotic Treatment}

The structural appearance of MRSA treated with concentrations of NS and in combination with antibiotics was analyzed using SEM. Figure 4A shows MRSA 4 clusters displaying well-formed shapes, while bacterial cell surface disruption is seen in $4 \mathrm{~B}$ after treatment with $5.0 \mu \mathrm{g} / \mathrm{mL}$ NS. In Figure 4C,D, cellular aggregation of bacteria and cell destruction is seen in combined treatments of NS with oxacillin and augmentin. In Figure 4E,F, similar destruction of bacteria cell surface and cellular aggregation were observed in the combined treatment of MRSA 5 with $7.5 \mu \mathrm{g} / \mathrm{mL}$ NS, augmentin, and cefuroxime. Figure 5A-F represent TEM monograph analysis of the different MRSA isolates with NS 5 and $7.5 \mu \mathrm{g} / \mathrm{mL}$ concentrations. Figure 5A shows altered MRSA 5 cell membranes and dead bacterial cells after exposure to $5.0 \mu \mathrm{g} / \mathrm{mL}$ NS. The figure also shows disruption of bacterial cell division. Figure $5 \mathrm{~B}$ also shows MRSA 4 cell wall damage after exposure to $7.5 \mu \mathrm{g} / \mathrm{mL}$ NS with oxacillin, as well as vacuoles created in the cytoplasm and perhaps the accumulation of NS within the cell. Figure $5 \mathrm{C}$ shows dead bacteria cells and a damaged cell wall in MRSA 4 treated with $7.5 \mu \mathrm{g} / \mathrm{mL}$ and augmentin, while Figure 5D displays MRSA 4 isolates treated with a combination of $7.5 \mu \mathrm{g} / \mathrm{mL}$ and cefuroxime. Figure 5E shows the effects of MRSA 1 treated with $5.0 \mu \mathrm{g} / \mathrm{mL}$ NS plus oxacillin and Figure 5F shows the effect on MRSA 1 treated with $5.0 \mu \mathrm{g} / \mathrm{mL}$ NS plus augmentin, showing cell wall destruction (black arrows). These micrographs show that NS disrupts the MRSA bacterial cell wall, thereby causing cell death. In combination with $\beta$-lactam antibiotics, these effects were potentiated and can be described as a bactericidal effect.

TEM interpretation of combined treatment of NS and antibiotics is shown in Figure 6A-F. The figure gives TEM monographs of the different MRSA bacterial isolates treated with a combination of $7.5 \mu \mathrm{g} / \mathrm{mL}$ NS concentrations and antibiotics. Figure $6 \mathrm{~A}$ shows damaged MRSA 4 cell walls, disrupted bacterial replication, and cell death with oxacillin. The figure also shows more cell death due to fewer cells, with similar observations seen with MRSA 5 in Figure 6B. In combination treatments with augmentin on MRSA 1, Figure 6C shows more cell deaths, while Figure $6 \mathrm{D}$ also displays cell death and the disruption of cell division in MRSA 5. Additionally, the TEM images in Figure 6E show the effect of treatments with $7.5 \mu \mathrm{g} / \mathrm{mL}$ NS in combination with cefuroxime led to MRSA 1 complete and incomplete cell wall disrupted and bacterial cell death. Figure $6 \mathrm{~F}$ shows complete destruction by $7.5 \mu \mathrm{g} / \mathrm{mL}$ NS plus cefuroxime in MRSA 5 . These effects clearly indicate that the combinations were bactericidal.

\subsection{Results of GC-MS Analysis}

The GC-MS analysis of volatile compounds contained in N. sativa oil used in this study showed that the major components were thymoquinone at $7.85 \%$, $p$-cymene at $5.18 \%$, trans-anethole at $1.52 \%$, and linalool at $1.12 \%$, as presented in Table 3 and Figure 7.

Table 3. GC-MS data.

\begin{tabular}{ccc}
\hline Com Pound Name & Rt & Area (\%) \\
\hline$p$-Cymene & 9.841 & 5.18 \\
Linalool & 13.498 & 1.12 \\
Thymoquinone & 18.018 & 7.85 \\
trans-Anethole & 19.023 & 1.52 \\
$m$-Thymol & 19.872 & 0.71 \\
\hline
\end{tabular}



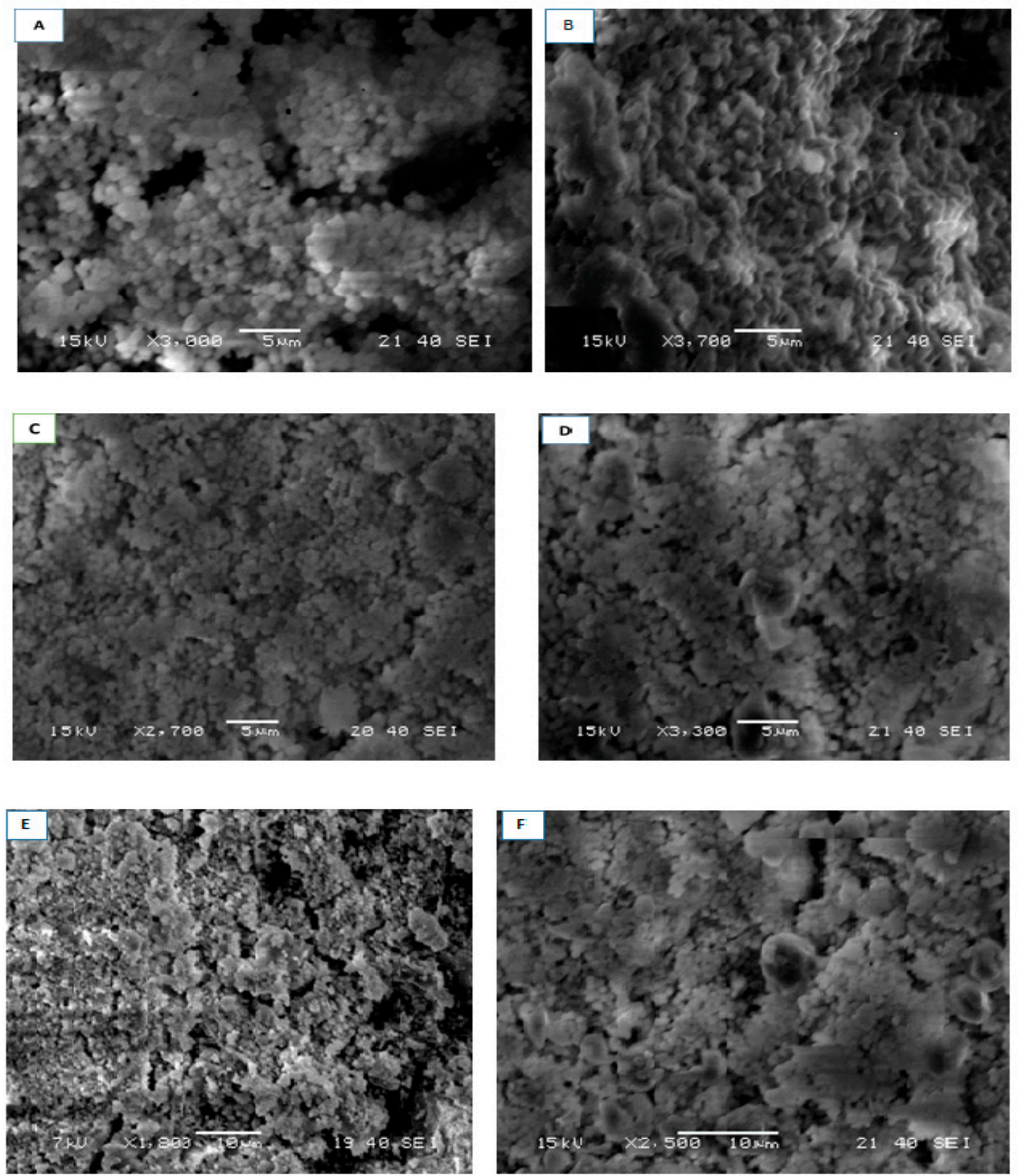

Figure 4. SEM micrographs of untreated, NS, and NS plus $\beta$-lactam antibiotics treated methicillin-resistant $S$. aureus isolates. (A) Control methicillin-resistant Staphylococcus aureus (MRSA 4) without any treatment, showing clusters of bacteria. (B) MRSA 4 treatment with $5.0 \mu \mathrm{g} / \mathrm{mL}$ Nigella sativa (NS), displaying surface alterations and destruction. (C) SEM of MRSA 4 treated with a combination of $5.0 \mu \mathrm{g} / \mathrm{mL}$ NS and oxacillin. (D) Augmentin combination with the same concentration of NS, showing surface destruction of S. aureus. (E) MRSA 5 at $2700 \times$ magnification showing $7.5 \mu \mathrm{g} / \mathrm{mL}$ NS treatment in combination with augmentin. (F) Combination treatment with cefuroxime and $7.5 \mu \mathrm{g} / \mathrm{mL}$ NS at $1800 \times$ showing MRSA 5 bacteria cluster surface destruction. 

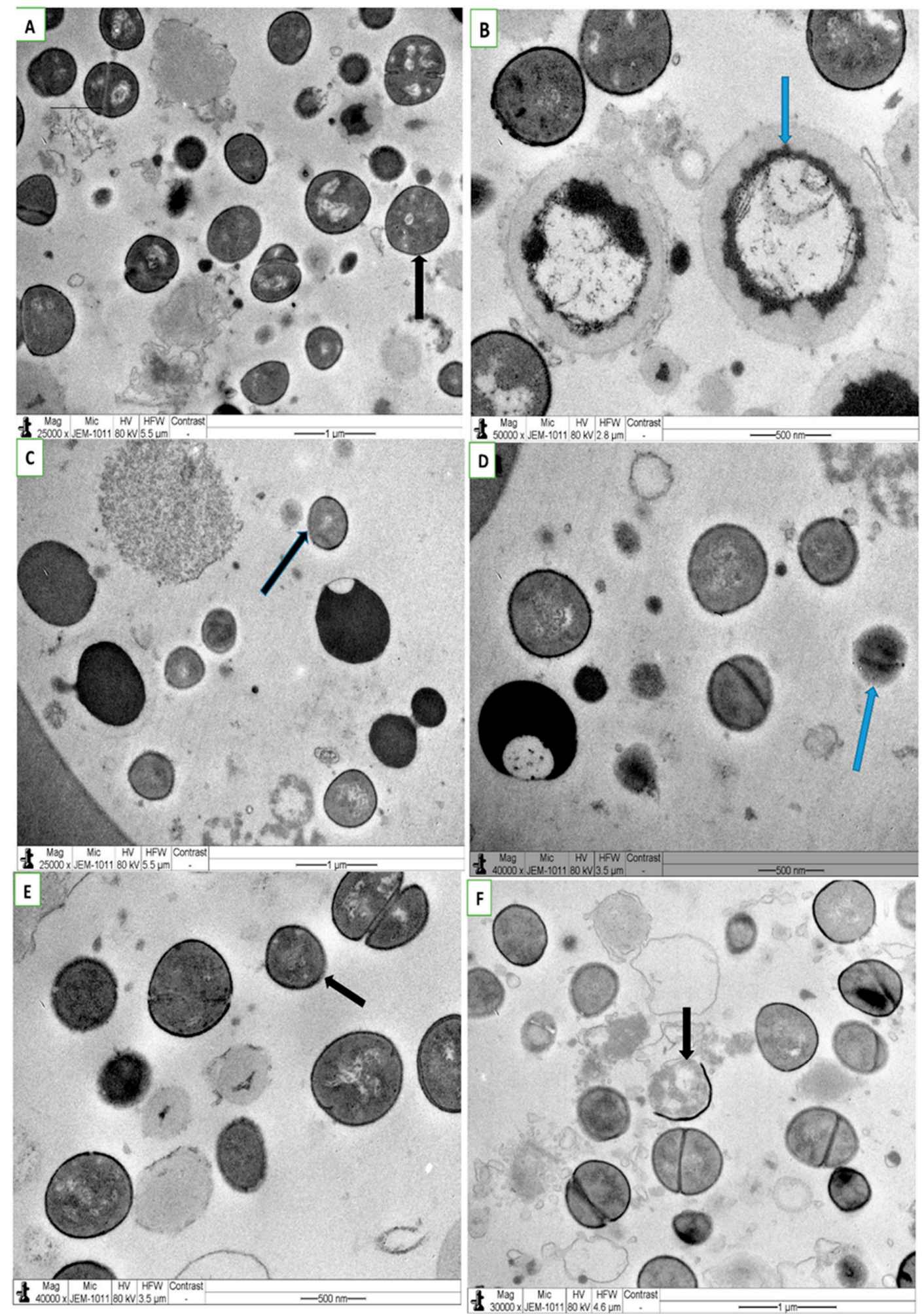

Figure 5. TEM micrographs of methicillin-resistant Staphylococcus aureus (MRSA) treated with NS and NS plus $\beta$-lactam antibiotics. (A) $5.0 \mu \mathrm{g} / \mathrm{mL}$ of NS at 25,000 $\times$ showing MRSA 5 cell wall destruction (black arrow). (B) $5.0 \mu \mathrm{g} / \mathrm{mL} \mathrm{NS}$ plus oxacillin showing MRSA 4 cell death at 50,000 $\times$ magnification (blue arrow). (C) MRSA 5 treated with NS $5.0 \mu \mathrm{g} / \mathrm{mL}$ plus augmentin at 25,000 $\times$ showing incomplete cell wall destruction (black arrow) and (D) MRSA 4 treated with $5.0 \mu \mathrm{g} / \mathrm{mL}$ NS plus cefuroxime showing cell death (blue arrow) at 40,000 $\times$ magnifications. (E) MRSA 1 treated with $5.0 \mu \mathrm{g} / \mathrm{mL}$ NS plus oxacillin and (F) MRSA 1 treated with $5.0 \mu \mathrm{g} / \mathrm{mL}$ NS plus augmentin, showing cell wall destruction (black arrows) at a magnification of $30,000 \times$. 


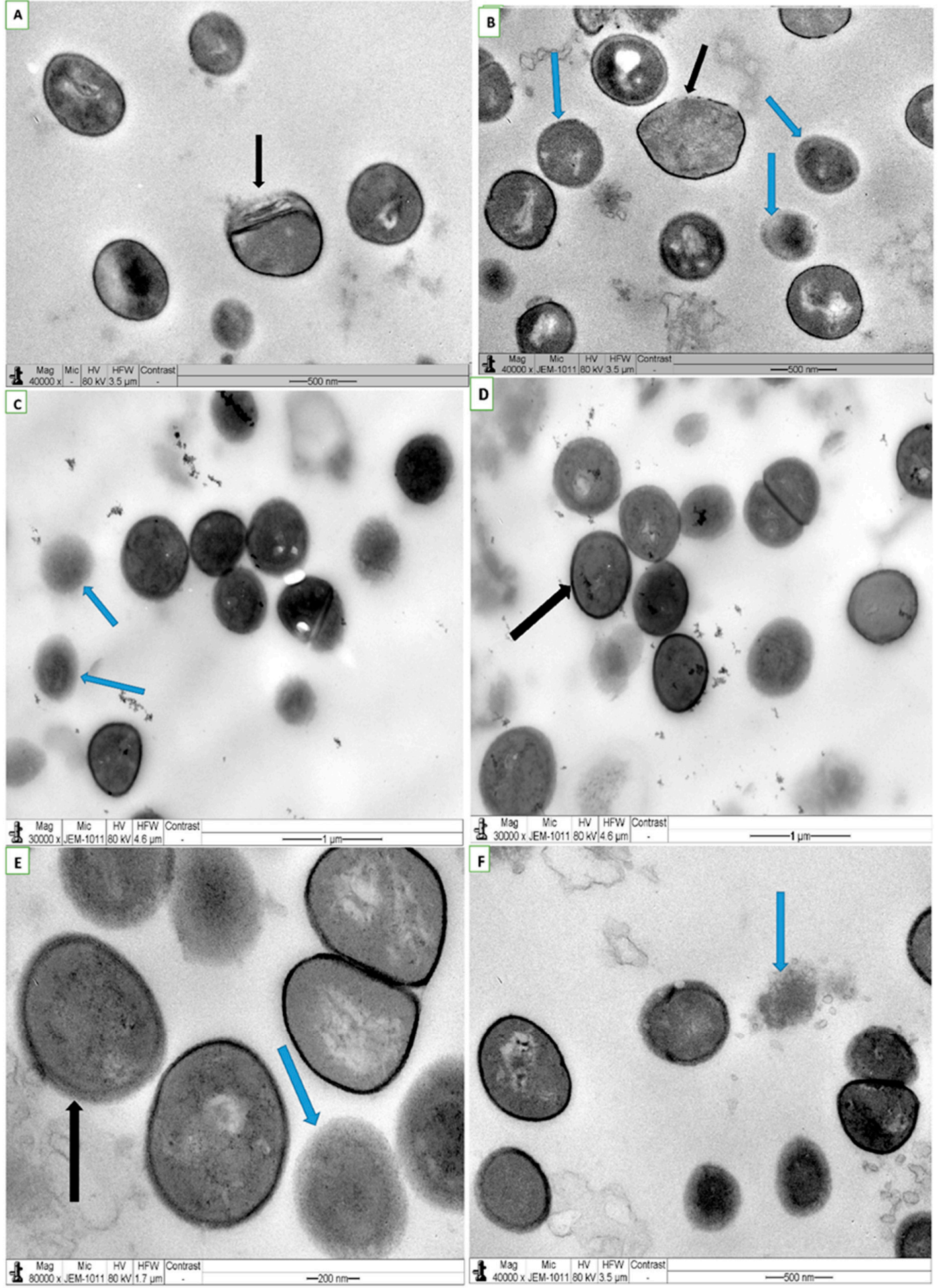

Figure 6. TEM micrographs of methicillin-resistant Staphylococcus aureus (MRSA) treated with NS and NS plus $\beta$-lactam antibiotics. (A) $7.5 \mu \mathrm{g} / \mathrm{mL}$ NS plus oxacillin at a magnification of 40,000 $\times$, showing incomplete destruction of MRSA 4 cell wall (black arrow) and (B) $7.5 \mu \mathrm{g} / \mathrm{mL}$ NS plus oxacillin, showing incomplete of destruction of MRSA 5 cell wall (blue arrow). (C) MRSA 1 treated with $7.5 \mu \mathrm{g} / \mathrm{mL} \mathrm{NS}$ plus augmentin, showing dead bacterial cells at a magnification of $30,000 \times$ (blue arrow). (D) MRSA 5 treated with $7.5 \mu \mathrm{g} / \mathrm{mL}$ NS plus augmentin, showing complete cell wall destruction. (E) $7.5 \mu \mathrm{g} / \mathrm{mL}$ NS plus cefuroxime, showing incomplete (black arrow) and complete (blue arrow) destruction of MRSA 1 cell wall at a magnification of $80,000 \times$. (F) Complete destruction by $7.5 \mu \mathrm{g} / \mathrm{mL}$ NS plus cefuroxime of MRSA 5 cell wall at a magnification of $40,000 \times$ (blue arrow). 


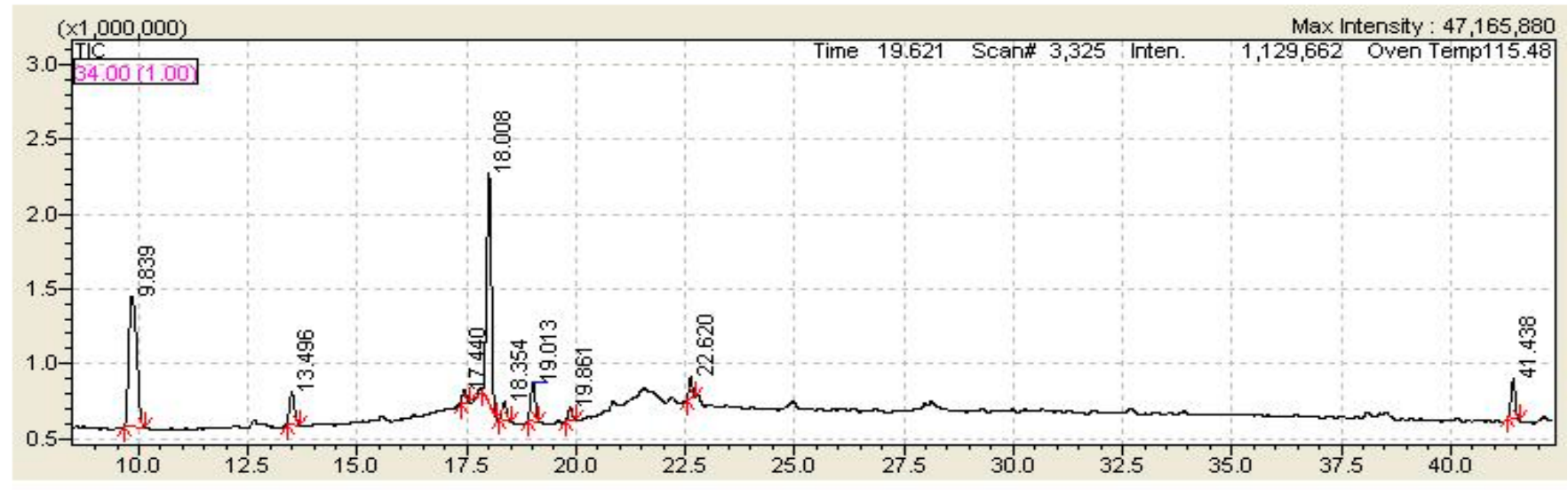

Figure 7. Chromatogram of N. Sativa oil characterized by GC-MS analysis.

\section{Discussion}

The MRSA isolates examined here were extremely drug-resistant and fit into the classification of $\mathrm{XDR}$, as they were resistant to aminoglycosides, $\beta$-lactams, fluoroquinolones, macrolides, and tetracycline [39-41]. However, this study has shown that Nigella sativa (NS), a naturally derived herbal product, inhibits the growth of these XDR MRSA isolates, thereby confirming earlier findings. This suggests that NS derivatives could serve as possible alternatives in the management of extreme drug-resistant (XDR) MRSA isolates. The inherent antimicrobial potential of NS derivatives had been reported as equally effective as that of clinically available antibiotics [26,32,42]. All these reports demonstrated better inhibition of MRSA isolates by NS as compared to commonly used antibiotics, as also seen in the present study.

In this investigation, the isolates responded differently to various concentrations of NS, as seen in the exhibited zones of inhibition. Additionally, although there were differences among the isolates in zones of inhibition, all NS concentrations, including the lowest concentration of $0.1 \mu \mathrm{g} / \mathrm{mL}$, were able to hinder bacterial growth, a finding that is similar to earlier reports [32,43]. Differences in zones of inhibition could be attributed to phenotypic differences in the MRSA strains. However, that the lowest concentration of NS exhibited growth inhibition against the isolates in this study points to its effectiveness as a potential antimicrobial.

The study also shows the time-kill kinetics for the MRSA strains used in this study to be more rapid in NS and $\beta$-lactam combined therapies than with NS alone. This suggests the possibility of a combined additive effect or potentiation of NS to those of the antibiotics that the MRSA isolates had previously been resistant to. These findings are in agreement with earlier suggestions for the need to develop a synergistic herbal drug product that could be suitable for use in combined therapeutic measures to combat the scourge of bacterial resistance [44-46]. Phytotherapy combinations with proven synergistic efficacy would not only have a multi-targeted mechanism of action but could be a main tool in delaying, alleviating, or reducing resistance to existing antimicrobials [32,44]. Additionally, our findings show NS synergistic activity in combination with OXA, AUG, and CEF against XDR MRSA isolates, with the best effect seen in the NS-AUG combination as opposed to NS-OXA and NS-CEF, similar to an earlier report [32]. This reported that, in NS $\beta$ lactam synergism, there was a reversal in resistance to augmentin by MRSA, findings that are similar to those of this investigation. An earlier report on the synergistic effects of combining the by-products contained in the plant with conventional antimicrobial drugs found improved effects compared to antimicrobials alone [47]. This might explain why all NS $\beta$-lactam combinations were more effective than NS or the antibiotic alone. On the other hand, that the combination of $0.5 \mathrm{mg} / \mathrm{mL}$ NS and $\beta$-lactam showed varying results (Figure 3D-F), with complete killing seen with MRSA 1, suggests that differences in bacterial strains could be a contributory factor, as had been reported previously [25]. 
However, that there was better killing against the same MRSA 4 and 5 isolates (Figure 3E,F) in the $7.5 \mu \mathrm{g} / \mathrm{mL}$ NS and antibiotic combinations could point to a dose-dependent NS concentration, a view expressed earlier [32]. Molecular insight was gained by examining the probable mechanism of action of NS alone and with $\beta$-lactam antibiotic combinations using SEM and TEM techniques. A SEM micrograph analysis showed bacterial cell aggregation without the usual well-defined clustering of $S$. aureus. This finding is consistent with previous studies that reported the effect of antibiotics on bacterial cells [48,49]. NS alone disrupted the bacterial cell surface and therefore caused destruction, which was evident in the bacterial growth inhibition. However, in the combinations of NS with OXA and AUG, where there was marked cellular aggregation/cell destruction, we can point to the possible synergistic/additive effects of NS, as shown in the FIC results in Tables 2 and 3, all of which created significant changes in the molecular ultrastructure that Gram-positive bacteria such as MRSA use for survival. It could also mean that binding of $\beta$-lactam antibiotics to penicillin binding protein (PBP) sites was significantly enhanced. Note that the isolates used in this study exhibited marked antimicrobial resistance. The TEM micrograph analysis also confirmed this view. It showed cell death and cell surface disruption, similar to the ultrastructural changes in the MRSA isolates from a previous study with NS alone [32]. The molecular structural changes seen in the TEM micrographs could also be due to interference in the transportation or the synthesis of PBP by NS. Such cell wall destruction, either by NS or in combination with $\beta$-lactam antibiotics, would be expected to remove the bacterial protective barriers, thus leading to cell lysis, as shown by the TEM micrograph results.

Generally, the mode of action of augmentin as a $\beta$-lactam is that it leads to the inhibition of bacterial cell wall peptidoglycan by binding and inhibiting PBPs [50]. It is documented that antimicrobial resistance results from the activation of the Mec A gene and its variants, which leads to the formation of penicillin-binding protein 2A (PBP2a), which binds to $\beta$-lactams, thus creating resistance [50]. However, we noted that alkaloid plant components, alone or when combined with conventional antibiotics, could have an effect on bacterial acquired resistance, which could explain the NS and antibiotic combined effects seen in this investigation [3].

$N$. sativa oil is rich in diverse volatile compounds involved in various biological activities [51]. The GC-MS results confirmed that $N$. sativa essential oil is a good source of bioactive components such as p-cymene, linalool, thymoquinone, transanethole, and $\mathrm{m}$ thymol, which have been evaluated by various reports and are considered to possess good antimicrobial activity [51-54]. Earlier reports documented synergistic effects of the extracts of black cumin with streptomycin and gentamicin against antibiotic sensitive S. aureus and other bacterial isolates $[55,56]$. Thymoquinone was indicated to exert synergism with the antibiotics against $S$. aureus [56]. Thus, thymoquinone an abundant component of $N$. sativa is reported to be the bioactive compound with multiple pharmacological actions including being a strong antimicrobial $[55,57]$. Additionally, as other reports show synergistic effects when thymoquinone is combined with synthetic and natural compound, the present study further confirms that the contents of $N$. sativa essential oil are potent at inhibiting bacterial activity $[54,58]$.

\section{Conclusions}

Our findings indicate that $N$. sativa had a bactericidal effect against XDR methicillinresistant Staphylococcus aureus, even at low concentration. NS synergistically improved the efficacy of $\beta$-lactam antibiotics to which, ab initio, they had been resistant. The study also showed, by SEM and TEM molecular analysis, that NS used bacterial cell wall disruption as a possible mechanism of action. This appeared to have improved the binding of $\beta$-lactam antibiotics to PBP, as evident in the destruction of the MRSA cell wall and lysis shown in TEM micrographs. However, further studies will be needed to evaluate in detail the nature of this binding and to what type of membrane protein in rapidly emerging resistant bacterial strains. 
Author Contributions: Conceptualization, methodology, formal analysis, and writing — original draft preparation, L.I.B.-E. and P.M.E.; software, P.M.E. and H.I.M.I.; validation, investigation, resources, data curation, and writing-review and editing, L.I.B.-E., P.M.E. and H.I.M.I.; funding acquisition, L.I.B.-E. All authors have read and agreed to the published version of the manuscript.

Funding: The Deanship of Scientific Research, King Faisal University (grant No. 186388) funded the research under Nasher Track.

Institutional Review Board Statement: Not required as isolates were routine diagnostic specimen.

Informed Consent Statement: Not applicable.

Data Availability Statement: Data is contained within the article and correspondence author can be contacted for more information.

Acknowledgments: The authors acknowledge the Deanship of Scientific Research, King Faisal University for the financial support. The authors would like to thank Maged El-Sayed Mohamed, Hani Al-Rasasi, Hajer Salman Al-Dehailan, Fatimah Mohammed Alquaimy, and Fatimah Ahmad AlJaafari for their technical assistance.

Conflicts of Interest: The authors declare no conflict of interest with respect to the research, authorship nor in the article publication.

\section{References}

1. Ippolito, G.; Leone, S.; Lauria, F.N.; Nicastri, E.; Wenzel, R.P. Methicillin-resistant Staphylococcus aureus: The superbug. Int. J. Infect. Dis. 2010, 14, S7-S11. [CrossRef]

2. Papp-Wallace, K.M.; Endimiani, A.; Taracila, M.A.; Bonomo, R.A. Carbapenems: Past, Present, and Future. Antimicrob. Agents Chemother. 2011, 55, 4943-4960. [CrossRef] [PubMed]

3. Konaté, K.; Mavoungou, J.F.; Lepengué, A.N.; Aworet-Samseny, R.R.; Hilou, A.; Souza, A.; Dicko, M.H.; M’Batchi, B. Antibacterial activity against $\beta$ - lactamase producing Methicillin and Ampicillin-resistants Staphylococcus aureus: Fractional Inhibitory Concentration Index (FICI) determination. Ann. Clin. Microbiol. Antimicrob. 2012, 11, 18. [CrossRef] [PubMed]

4. Bæk, K.T.; Gründling, A.; Mogensen, R.G.; Thøgersen, L.; Petersen, A.; Paulander, W.; Frees, D. $\beta$-Lactam Resistance in MethicillinResistant Staphylococcus aureus USA300 Is Increased by Inactivation of the ClpXP Protease. Antimicrob. Agents Chemother. 2014, 58, 4593-4603. [CrossRef]

5. McGuinness, W.A.; Malachowa, N.; DeLeo, F.R. Vancomycin Resistance in Staphylococcus aureus. Yale J. Biol. Med. 2017, 90, 269-281. [PubMed]

6. Lesho, E.; Yoon, E.-J.; McGann, P.; Snesrud, E.; Kwak, Y.; Milillo, M.; Onmus-Leone, F.; Preston, L.; Clair, K.S.; Nikolich, M.; et al. Emergence of Colistin-Resistance in Extremely Drug-Resistant Acinetobacter baumannii Containing a Novel pmrCAB Operon During Colistin Therapy of Wound Infections. J. Infect. Dis. 2013, 208, 1142-1151. [CrossRef]

7. Kaur, M.; Rai, J.; Randhawa, G.K. Recent advances in antibacterial drugs. Int. J. Appl. Basic Med. Res. 2013, 3, 3-10. [CrossRef] [PubMed]

8. Aslam, B.; Wang, W.; Arshad, M.I.; Khurshid, M.; Muzammil, S.; Rasool, M.H.; Nisar, M.A.; Alvi, R.F.; Aslam, M.A.; Qamar, M.U.; et al. Antibiotic resistance: A rundown of a global crisis. Infect. Drug Resist. 2018, 11, 1645-1658. [CrossRef]

9. Lee, K.; Yong, D.; Jeong, S.H.; Chong, Y. Multidrug-ResistantAcinetobacterspp.: Increasingly Problematic Nosocomial Pathogens. Yonsei Med. J. 2011, 52, 879-891. [CrossRef]

10. Lim, T.-P.; Tan, T.-Y.; Lee, W.; Sasikala, S.; Tan, T.-T.; Hsu, L.-Y.; Kwa, A.L. In-Vitro Activity of Polymyxin B, Rifampicin, Tigecycline Alone and in Combination against Carbapenem-Resistant Acinetobacter baumannii in Singapore. PLoS ONE 2011, 6, e18485. [CrossRef]

11. Albur, M.; Noel, A.; Bowker, K.; MacGowan, A. Bactericidal Activity of Multiple Combinations of Tigecycline and Colistin against NDM-1-Producing Enterobacteriaceae. Antimicrob. Agents Chemother. 2012, 56, 3441-3443. [CrossRef]

12. Urban, C.; Mariano, N.; Rahal, J.J. In Vitro Double and Triple Bactericidal Activities of Doripenem, Polymyxin B, and Rifampin against Multidrug-Resistant Acinetobacter baumannii, Pseudomonas aeruginosa, Klebsiella pneumoniae, and Escherichia coli. Antimicrob. Agents Chemother. 2010, 54, 2732-2734. [CrossRef] [PubMed]

13. Cai, Y.; Chai, D.; Wang, R.; Liang, B.; Bai, N. Colistin resistance of Acinetobacter baumannii: Clinical reports, mechanisms and antimicrobial strategies. J. Antimicrob. Chemother. 2012, 67, 1607-1615. [CrossRef] [PubMed]

14. Gharaibeh, M.H.; Shatnawi, S.Q. An overview of colistin resistance, mobilized colistin resistance genes dissemination, global responses, and the alternatives to colistin: A review. Veter. World 2019, 12, 1735-1746. [CrossRef] [PubMed]

15. Rhouma, M.; Beaudry, F.; Letellier, A. Resistance to colistin: What is the fate for this antibiotic in pig production? Int. J. Antimicrob. Agents 2016, 48, 119-126. [CrossRef] [PubMed]

16. Liu, Y.-Y.; Wang, Y.; Walsh, T.R.; Yi, L.-X.; Zhang, R.; Spencer, J.; Doi, Y.; Tian, G.; Dong, B.; Huang, X.; et al. Emergence of plasmid-mediated colistin resistance mechanism MCR-1 in animals and human beings in China: A microbiological and molecular biological study. Lancet Infect. Dis. 2016, 16, 161-168. [CrossRef] 
17. Barbieri, N.L.; Nielsen, D.W.; Wannemuehler, Y.; Cavender, T.; Hussein, A.; Yan, S.-G.; Nolan, L.K.; Logue, C.M. mcr-1 identified in Avian Pathogenic Escherichia coli (APEC). PLoS ONE 2017, 12, e0172997. [CrossRef] [PubMed]

18. Elsayed, A.; Abdulrahman, A.A.; Aboulmagd, E.; Alsultan, A.A. Synergic bactericidal activity of novel antibiotic combinations against extreme drug resistant Pseudomonas aeruginosa and Acinetobacter baumannii. Afr. J. Microbiol. Res. 2014, 8, 856-861. [CrossRef]

19. Pena-Miller, R.; Laehnemann, D.; Jansen, G.; Fuentes-Hernandez, A.; Rosenstiel, P.; Schulenburg, H.; Beardmore, R. When the Most Potent Combination of Antibiotics Selects for the Greatest Bacterial Load: The Smile-Frown Transition. PLoS Biol. 2013, 11, e1001540. [CrossRef] [PubMed]

20. Sibanda, T.; Okoh, A.I. The challenges of overcoming antibiotic resistance: Plant extracts as potential sources of antimicrobial and resistance modifying agents. Afr. J. Biotechnol. 2007, 6, 2886-2896.

21. Hübsch, Z.; Van Zyl, R.; Cock, I.; Van Vuuren, S. Interactive antimicrobial and toxicity profiles of conventional antimicrobials with Southern African medicinal plants. S. Afr. J. Bot. 2014, 93, 185-197. [CrossRef]

22. Aiyegoro, O.A.; Okoh, A.I. Use of bioactive plant products in combination with standard antibiotics: Implications in antimicrobial chemotherapy. J. Med. Plant Res. 2009, 3, 1147-1152.

23. Haroun, M.F.; Al-Kayali, R.S. Synergistic effect of Thymbra spicata L. extracts with antibiotics against multidrug- resistant Staphylococcus aureus and Klebsiella pneumoniae strains. Iran. J. Basic Med. Sci. 2016, 19, 1193-1200. [PubMed]

24. Teow, S.-Y.; Liew, K.; Ali, S.A.; Khoo, A.S.-B.; Peh, S.-C. Antibacterial Action of Curcumin against Staphylococcus aureus: A Brief Review. J. Trop. Med. 2016, 2016, 1-10. [CrossRef]

25. Emeka, L.B.; Emeka, P.M.; Khan, T.M. Antimicrobial activity of Nigella sativa L. seed oil against multi-drug resistant Staphylococcus aureus isolated from diabetic wounds. Pak. J. Pharm. Sci. 2015, 28, 1985-1990. [PubMed]

26. Ugur, A.R.; Dagi, H.T.; Ozturk, B.; Tekin, G.; Findik, D. Assessment of In vitro antibacterial activity and cytotoxicity effect of Nigella sativa oil. Pharmacogn. Mag. 2016, 12, 471-S474. [CrossRef] [PubMed]

27. Utami, A.T.; Pratomo, B.; Noorhamdani. Study of Antimicrobial Activity of Black Cumin Seeds (Nigella sativa L.) Against Salmonella typhi In Vitro. J. Med. Surg. Pathol. 2016, 1, 3. [CrossRef]

28. Emeka, P.M.; Badger-Emeka, L.I.; Eneh, C.M.; Khan, T.M. Dietary supplementation of chloroquine with nigella sativa seed and oil extracts in the treatment of malaria induced in mice with plasmodium berghei. Pharmacogn. Mag. 2014, 10, S357-S362. [CrossRef] [PubMed]

29. Magaldi, S.; Mata-Essayag, S.; de Capriles, C.H.; Perez, C.; Colella, M.; Olaizola, C.; Ontiveros, Y. Well diffusion for antifungal susceptibility testing. Int. J. Infect. Dis. 2004, 8, 39-45. [CrossRef]

30. Balouiri, M.; Sadiki, M.; Ibnsouda, S.K. Methods for in vitro evaluating antimicrobial activity: A review. J. Pharm. Anal. 2016, 6, 71-79. [CrossRef] [PubMed]

31. CLSI. Methods for Determining Bactericidal Activity of Antimicrobial Agents; Approved Guideline, CLSI document M26-A; Clinical and Laboratory Standards Institute: Wayne, PA, USA, 1998.

32. Uzair, B.; Hameed, A.; Nazir, S.; Khan, B.A.; Fasim, F.; Khan, S.; Menaa, F. Synergism Between Nigella sativa Seeds Extract and Synthetic Antibiotics Against Mec A Gene Positive Human Strains of Staphylococcus aureus. Int. J. Pharmacol. 2017, 13, 958-968. [CrossRef]

33. Sopirala, M.M.; Mangino, J.E.; Gebreyes, W.A.; Biller, B.; Bannerman, T.; Balada-Llasat, J.-M.; Pancholi, P. Synergy Testing by Etest, Microdilution Checkerboard, and Time-Kill Methods for Pan-Drug-Resistant Acinetobacter baumannii. Antimicrob. Agents Chemother. 2010, 54, 4678-4683. [CrossRef] [PubMed]

34. Meletiadis, J.; Pournaras, S.; Roilides, E.; Walsh, T.J. Defining fractional inhibitory concentration index cut offs for additive interactions based on self-drug additive combinations, Monte Carlo simulation analysis, and in vitro-in vivo correlation data for antifungal drug combinations against Aspergillus fumigatus. Antimicrob. Agents Chemother. 2010, 54, 602-609. [CrossRef]

35. Meletiadis, J.; Mouton, J.W.; Meis, J.F.G.M.; Bouman, B.A.; Donnelly, P.J.; Verweij, P.E.; Eurofung Network. Comparison of Spectrophotometric and Visual Readings of NCCLS Method and Evaluation of a Colorimetric Method Based on Reduction of a Soluble Tetrazolium Salt, 2,3-Bis \{2-Methoxy-4-Nitro-5-[(Sulfenylamino) Carbonyl]-2H- Tetrazolium-Hydroxide\}, for Antifungal Susceptibility Testing of Aspergillus Species. J. Clin. Microbiol. 2001, 39, 4256-4263. [CrossRef] [PubMed]

36. Thammawat, S.; Sangdee, K. Time-kill profiles and cell-surface morphological effects of crude Polycephalomyces nipponicus Cod-MK1201 mycelial extract against antibiotic-sensitive and -resistant Staphylococcus aureus. Trop. J. Pharm. Res. 2017, 16, 407. [CrossRef]

37. Thomas, P.; Reddy, K.M. Microscopic elucidation of abundant endophytic bacteria colonizing the cell wall-plasma membrane peri-space in the shoot-tip tissue of banana. AoB Plants 2013, 5, 11. [CrossRef]

38. Ran, Y.; Hu, W.; Zhuang, K.; Lu, M.; Huang, J.; Xu, F.; Xu, X.; Hua, X.; Lama, J.; Ran, X.; et al. Observation of Viruses, Bacteria, and Fungi in Clinical Skin Samples under Transmission Electron Microscopy. In The Transmission Electron Microscope-Theory and Applications; Khan Maaz; IntechOpen: Rijeka, Croatia, 2015. [CrossRef]

39. Falagas, M.E.; Karageorgopoulos, D.E. Pandrug Resistance (PDR), Extensive Drug Resistance (XDR), and Multidrug Resistance (MDR) among Gram-Negative Bacilli: Need for International Harmonization in Terminology. Clin. Infect. Dis. 2008, 46, 1121-1122. [CrossRef] [PubMed]

40. Basak, S.; Singh, P.; Rajurkar, M. Multidrug Resistant and Extensively Drug Resistant Bacteria: A Study. J. Pathog. 2016, 2016, 1-5. [CrossRef] [PubMed] 
41. Sweeney, M.T.; Lubbers, B.V.; Schwarz, S.; Watts, J.L. Applying definitions for multidrug resistance, extensive drug resistance and pandrug resistance to clinically significant livestock and companion animal bacterial pathogens. J. Antimicrob. Chemother. 2018, 73, 1460-1463. [CrossRef] [PubMed]

42. Naz, H. Nigella sativa: The miraculous herb. Pak. J. Biochem. Mol. Biol. 2011, 44, 44-48. Available online: http://pjbmb.org.pk/ images/PJBMBArchive/2011/PJBMB_44_1_Mar_2011/10.pdf (accessed on 26 March 2021).

43. Chaieb, K.; Kouidhi, B.; Jrah, H.; Mahdouani, K.; Bakhrouf, A. Antibacterial activity of Thymoquinone, an active principle of Nigella sativa and its potency to prevent bacterial biofilm formation. BMC Complement. Altern. Med. 2011, 11, 29. [CrossRef] [PubMed]

44. Wagner, H. Synergy research: Approaching a new generation of phytopharmaceuticals. Fitoterapia 2011, 82, 34-37. [CrossRef] [PubMed]

45. Ventola, C.L. The antibiotic resistance crisis: Part 1: Causes and threats. Pharm. Ther. 2015, 40, 277-283. Available online: https: / / www.ncbi.nlm.nih.gov/pubmed/25859123 (accessed on 26 March 2021).

46. Thakur, P.; Chawla, R.; Goel, R.; Narula, A.; Arora, R.; Sharma, R.K. Augmenting the potency of third-line antibiotics with Berberis aristata: In vitro synergistic activity against carbapenem-resistant Escherichia coli. J. Glob. Antimicrob. Resist. 2016, 6, 10-16. [CrossRef] [PubMed]

47. Rosato, A.; Vitali, C.; De Laurentis, N.; Armenise, D.; Milillo, M.A. Antibacterial effect of some essential oils administered alone or in combination with Norfloxacin. Phytomedicine 2007, 14, 727-732. [CrossRef]

48. Ozkaya, G.U.; Durak, M.Z.; Akyar, I.; Karatuna, O. Antimicrobial Susceptibility Test for the Determination of Resistant and Susceptible S. aureus and Enterococcus spp. Using a Multi-Channel Surface Plasmon Resonance Device. Diagnostics 2019, 9, 191. [CrossRef]

49. Park, H.; Jang, C.-H.; Cho, Y.B.; Choi, C.-H. Antibacterial effect of tea-tree oil on methicillin-resistant Staphylococcus aureus biofilm formation of the tympanostomy tube: An in vitro study. In Vivo 2008, 21, 1027-1030.

50. Pinho, M.G.; Filipe, S.R.; De Lencastre, H.; Tomasz, A. Complementation of the Essential Peptidoglycan Transpeptidase Function of Penicillin-Binding Protein 2 (PBP2) by the Drug Resistance Protein PBP2A in Staphylococcus aureus. J. Bacteriol. 2001, 183, 6525-6531. [CrossRef] [PubMed]

51. Kazemi, M. Phytochemical Composition, Antioxidant, Anti-inflammatory and Antimicrobial Activity ofNigella sativaL. Essential Oil. J. Essent. Oil Bear. Plants 2014, 17, 1002-1011. [CrossRef]

52. Herman, A.; Tambor, K.; Herman, A. Linalool Affects the Antimicrobial Efficacy of Essential Oils. Curr. Microbiol. 2015, 72, 165-172. [CrossRef]

53. Forouzanfar, F.; Bazzaz, B.S.F.; Hosseinzadeh, H. Black cumin (Nigella sativa) and its constituent (thymoquinone): A review on antimicrobial effects. Iran. J. Basic Med. Sci. 2014, 17, 929-938. [PubMed]

54. Kwiatkowski, P.; Pruss, A.; Masiuk, H.; Mnichowska-Polanowska, M.; Kaczmarek, M.; Giedrys-Kalemba, S.; Dołęgowska, B.; Zielińska-Bliźniewska, H.; Olszewski, J.; Sienkiewicz, M. The effect of fennel essential oil and trans-anethole on antibacterial activity of mupirocin against Staphylococcus aureus isolated from asymptomatic carriers. Adv. Dermatol. Allergol. 2019, 36, 308-314. [CrossRef] [PubMed]

55. Halawani, E. Antibacterial activity of thymoquinone and thymohydroquinone of Nigella sativa L. and their interaction with some antibiotics. Adv. Biol. Res. 2009, 3, 148-152.

56. Elnour, S.A.; Abdelsalam, E.B. Some Biological and Pharmacological Effects of the Black Cumin (Nigella sativa): A Concise Review. Am. J. Res. Commun. 2018, 6, 10-35. Available online: http://www.usa-journals.com/wp-content/uploads/2018/02/ Elnour_Vol63.pdf (accessed on 26 March 2021).

57. Sahak, M.K.A.; Kabir, N.; Abbas, G.; Draman, S.; Hashim, N.H.; Adli, D.S.H. The Role ofNigella sativaand Its Active Constituents in Learning and Memory. Evid. Based Complement. Altern. Med. 2016, 2016, 1-6. [CrossRef]

58. Dera, A.A.; Ahmad, I.; Rajagopalan, P.; Al Shahrani, M.; Saif, A.; Alshahrani, M.Y.; Alraey, Y.; Alamri, A.M.; Alasmari, S.; Makkawi, M.; et al. Synergistic efficacies of thymoquinone and standard antibiotics against multi-drug resistant isolates. Saudi. Med. J. 2021, 42, 196-204. [CrossRef] [PubMed] 